\title{
Environmental impact of emissions from incineration plants in comparison to typical heating systems
}

\author{
Grzegorz Wielgosiński ${ }^{1}{ }^{*}$, Olga Namiecińska ${ }^{1}$, and Justyna Czerwińska ${ }^{1}$ \\ ${ }^{1}$ Lodz University of Technology, Faculty of Process and Environmental Engineering, \\ ul. Wólczańska 175, 90-924 Łódź, Poland
}

\begin{abstract}
In recent years, five modern municipal waste incineration plants have been built in Poland. Next ones are being constructed and at the same time building of several others is being considered. Despite positive experience with the operation of the existing installations, each project of building a new incinerator raises a lot of emotions and social protests. The main argument against construction of an incineration plant is the emission of pollutants. The work compares emissions from municipal waste incineration plants with those from typical heating plants: in the first part, for comparison large heating plants equipped with pulverized coal-fired boilers (OP-140), stoker-fired boilers (three OR-32 boilers) or gas blocks with heat output of about $100 \mathrm{MW}$ have been selected, while the second part compares WR10 and WR-25 stoker-fired boilers most popular in our heating industry with thermal treatment systems for municipal waste or refuse-derived-fuel (RDF) with similar heat output. Both absolute emission and impact - immission of pollutants in vicinity of the plant were analyzed.
\end{abstract}

\section{Introduction}

Among all waste generated in Poland the biggest problem is the municipal waste. Due to the complex and unstable composition its processing is a huge problem. According to the Central Statistical Office, the total amount of produced waste is about 10-12 million $\mathrm{Mg}$ a year [1]. Out of many municipal waste management methods the most effective is thermal treatment. In many EU countries incineration accounts for up to $60 \%$ of the methods used, but in Poland this level does not exceed 10\% [2]. In recent years, five modern municipal waste incineration plants have been built (Białystok, Bydgoszcz, Konin, Kraków, Poznań), the next one in Szczecin will start at the end of this year. Adding to that the existing incineration plant in Warsaw, which has been operating since 2001, the capacity of Polish incineration plants is approximately 1 million $\mathrm{Mg}$ of waste per year [3].

The currently functioning model of waste management is based on the regional waste treatment facilities (so called Waste-to-Energy Plants - WtEs), which are mechanicalbiological waste treatment installations (MBTs). In recent years, more than 150 such installations have been built with a capacity of nearly 11 million $\mathrm{Mg}$, generating 2.5 to 3.5 million Mg of combustible fractions, called alternative fuels, refuse-derived-fuel - RDF or pre-RDF. It is important that since January 1, 2016, an alternative fuel fraction, due to its high calorific value, cannot be deposited [4]. This fraction can and should be incinerated in

*Corresponding author: grzegorz.wielgosinski@p.lodz.pl 
waste incineration plants and co-incineration plants, in cement plants or used in heat or power plants. In the last case, these installations, due the rigorous emission regulations, must be equipped in sophisticated flue gas treatment system and this is a serious financial problem [5].

Any new proposal to build an installation for thermal treatment of municipal waste and RDF fractions is subject to numerous protests. The most important argument against construction is the emission of pollutants. However, in accordance with the requirements of the Environmental Protection Act, the operation of the installation should not cause exceedance of emission standards that are very stringent in the case of waste incineration and environmental quality standards. Therefore the legislation guarantees a low environmental impact [6].

It was decided to analyze the absolute amount of pollutant emissions as well as the amount of pollutants emitted in vicinity of the waste incineration plants as compared to similar emissions from heating plants that are common in our country. In the analyzed heating plants (heat and power plants) there are both stoker-fired boilers as well as pulverized coal-fired boilers and relatively rarely used gas blocks. The first part of the work focused on the comparison of commonly used boilers fired with hard coal (pulverized coalfired boilers OP-140, and stoker-fired boilers OR-32) and gas blocks with an installation for thermal treatment of municipal waste and RDF fraction of similar heat output. In the second part, calculations for WR-10 and WR-25 stoker-fired boilers are compared with the systems for thermal treatment of RDF or pre-RDF fractions.

\section{Research methods}

\subsection{Assumptions for calculations}

Two cases were investigated: the first is a comparison of the emissions of OP-140 pulverized coal-fired boilers (the smallest currently produced) commonly used in power plants, OR-32 stoker-fired boilers and gas blocks of similar total heat output, with the emissions from thermal waste treatment facility - (Waste-to-Energy - WtE) - a classical incineration plant and thermal waste treatment installation fired with alternative RDF fuel (WtE-RDF). For comparison, power plants operating in high-efficiency cogeneration - like in incineration plants, were selected. In the second case, a comparison was made between emissions from WR-10 and WR-25 stoker-fired boilers common in the Polish heating industry (respectively $30 \%$ and $10 \%$ of all heating boilers in Poland [7]) and the thermal Refuse Derived Fuel - RDF treatment installations with similar heat output. This is important because in the light of not yet implemented in the Polish law but the existing directive on medium combustion plants (MCPs) the present WR type boilers do not have any chance of meeting the requirements of this directive [8] and will have to be replaced by new installations [9].

In the first part of the calculations, a nominal heat output of the boiler equal to $105 \mathrm{MW}_{\mathrm{t}}$ was assumed. This value results from the capacity of one of the smallest pulverized coal-fired boilers produced and used in Poland, i.e. OP-140. This variant was compared with a stoker-fired boiler also fired with hard coal - in this case the assumed heat output can be provided by three OR-32 boilers. It was assumed that the analyzed boiler should be a steam boiler so that by analogy to the waste incinerator it would work in cogeneration. As a third variant to compare, a gas boiler also of output $105 \mathrm{MW}_{\mathrm{t}}$ was selected. Total capacity of the boiler in the case of waste incineration plant also remained at the same level. At the assumed heating value of mixed municipal waste at an average level 
of about $7.5 \mathrm{MJ} / \mathrm{kg}$, this means the incineration plant capacity of $440,000 \mathrm{Mg} / \mathrm{year}$, i.e. twice as large as the largest Polish incineration plant for mixed municipal waste in Cracow with a capacity of $220,000 \mathrm{mg} /$ year. In addition, the RDF incineration plant has been analyzed, assuming that it will incinerate approximately $235,000 \mathrm{Mg}$ of RDF per year with a net calorific value of $14 \mathrm{MJ} / \mathrm{kg}$ and will have a nominal heat output of $105 \mathrm{MW}_{\mathrm{t}}$.

The basic characteristics of the installation for the five variants analyzed are presented in Table 1.

Table 1. Basic characteristics of the installation for five variants analyzed in first comparison.

\begin{tabular}{|c|c|c|c|c|c|c|}
\hline Boiler & Unit & OP-140 & 3 x OR-32 & Gas block & WtE & WtE-RDF \\
\hline Heat output & $\mathrm{MW}_{\mathrm{t}}$ & 105.0 & 105.0 & 105.0 & 105.1 & 105.0 \\
\hline Efficiency & $\%$ & 90 & 85 & 92 & 86 & 86 \\
\hline $\begin{array}{c}\text { Flue gas } \\
\text { temperature }\end{array}$ & ${ }^{\circ} \mathrm{C}$ & 130 & 140 & 160 & 120 & 120 \\
\hline $\begin{array}{c}\text { Fuel net } \\
\text { calorific } \\
\text { value }\end{array}$ & $\begin{array}{c}{ }^{*} \mathrm{MJ} / \mathrm{kg} \\
\mathrm{MJ} / \mathrm{m}^{3}\end{array}$ & 21.0 & 23.0 & $\left.34.5^{*}\right)$ & 7.5 & 14.0 \\
\hline
\end{tabular}

The second part analyzes pollutant emissions from some of the WR-10 and WR-25 stoker-fired boilers most frequently used in the Polish heating industry. Heat output of the WR-25 boiler is about $30 \mathrm{MW}_{\mathrm{t}}$ and, as in the previous case, the efficiency of the RDF thermal treatment system has been adjusted to the same level. With an assumed net calorific value of RDF equal to about $14.0 \mathrm{MJ} / \mathrm{kg}$, this means a capacity of $67,500 \mathrm{Mg} / \mathrm{year}$. In the case of the WR-10 boiler, the nominal heat output is about $12 \mathrm{MW}_{\mathrm{t}}$ which, at the calorific value of RDF, results in capacity of about $27,000 \mathrm{Mg} /$ year. The calorific value of coal in both cases was assumed to be $21 \mathrm{MJ} / \mathrm{kg}$. The characteristics of individual boilers are shown in Table 2.

Table 2. Basic installation characteristics of WR-10 and WR-25 boilers compared to the corresponding WtE-RDF plants in second comparison.

\begin{tabular}{|c|c|c|c|c|c|}
\hline Boiler & Unit & WR-25 & WtE-RDF & WR-10 & WtE-RDF \\
\hline Heat output & $\mathrm{MW}_{\mathrm{t}}$ & 30.0 & 30.1 & 12.0 & 10.0 \\
\hline Efficiency & $\%$ & 84 & 86 & 82 & 86 \\
\hline $\begin{array}{c}\text { Flue gas } \\
\text { temperature }\end{array}$ & ${ }^{\circ} \mathrm{C}$ & 130 & 4120 & 130 & 120 \\
\hline $\begin{array}{c}\text { Fuel net } \\
\text { calorific value }\end{array}$ & $\mathrm{MJ} / \mathrm{kg}$ & 21.0 & 14.0 & 21.0 & 14.0 \\
\hline
\end{tabular}

\subsection{Maximum and average annual fuel consumption}

Then, based on the data in Table 1 and 2 (for both variants), the maximum instantaneous fuel consumption and the average annual fuel consumption was calculated. Next, using the Recknagel relationships [10] the maximum flue gas flow rate was calculated for the operating conditions of the system and converted into assumed conditions (temperature: $273 \mathrm{~K}$, pressure: $1013 \mathrm{hPa}$, dry gas, assumed oxygen content in the exhaust gas: $3 \%$ for the gas block, $6 \%$ for coal-fired boilers and $11 \%$ for waste incineration plants in both variants). 
Results of these calculations are given in Tables 3 and 4 . The values of excess air ratio (oxygen concentration in the flue gas) and the flue gas humidity were based on the data obtained from potential installation suppliers.

Table 3. The most important operating parameters of the system for five variants analyzed.

\begin{tabular}{|c|c|c|c|c|c|c|}
\hline Boiler & Unit & OP-140 & 3 x OR-32 & Gas block & WtE & WtE-RDF \\
\hline $\begin{array}{c}\text { Maximum fuel } \\
\text { consumption }\end{array}$ & $\begin{array}{c}\mathrm{Mg} / \mathrm{h} \\
*) \\
\mathrm{m}^{3} / \mathrm{h}\end{array}$ & 20.0 & 19.3 & $11909^{*)}$ & 58.7 & 31.4 \\
\hline $\begin{array}{c}\text { Annual fuel } \\
\text { consumption }\end{array}$ & $\begin{array}{c}\mathrm{Mg} / \text { year } \\
{ }^{*} \mathrm{~m} / 3 / \text { year }\end{array}$ & 150000 & 145013 & $\begin{array}{c}8931947 \\
1^{*)}\end{array}$ & 440003 & 235500 \\
\hline Excess air ratio & - & 1.3 & 1.6 & 1.1 & 2.3 & 2.3 \\
\hline $\begin{array}{c}\text { Oxygen concen- } \\
\text { tration in flue gas }\end{array}$ & $\%$ & 4.51 & 7.50 & 1.74 & 10.10 & 10.95 \\
\hline Flue gas humidity & $\%$ & 7.5 & 5.5 & 6 & 16 & 16 \\
\hline Flue gas flow rate & $\mathrm{m}^{3} / \mathrm{h}$ & 229409 & 296945 & 198448 & 526976 & 436391 \\
\cline { 2 - 8 } & $\mathrm{m}^{3} \mathrm{u} / \mathrm{h}$ & 158042 & 166937 & 125825 & 335303 & 252744 \\
\hline
\end{tabular}

Table 4. The most important operating parameters for WR-10 and WR-25 boilers as compared to the corresponding WtE-RDF.

\begin{tabular}{|c|c|c|c|c|c|}
\hline Boiler & Unit & WR-25 & WtE-RDF & WR-10 & WtE-RDF \\
\hline Maximum fuel consumption & $\mathrm{Mg} / \mathrm{h}$ & 6.1 & 9.0 & 2.5 & 3.6 \\
\hline Annual fuel consumption & $\mathrm{Mg} / \mathrm{year}$ & 45918 & 67500 & 18815 & 27000 \\
\hline Excess air ratio & - & 1.3 & 2.3 & 1.3 & 2.3 \\
\hline $\begin{array}{c}\text { Oxygen concentration } \\
\text { in flue gas }\end{array}$ & $\%$ & 4.51 & 10.95 & 4.51 & 10.95 \\
\hline Flue gas humidity & $\%$ & 7.5 & 17 & 7.5 & 17 \\
\hline Flue gas flow rate & $\mathrm{m}^{3} / \mathrm{h}$ & 70227 & 125080 & 28776 & 50032 \\
\cline { 2 - 7 } & $\mathrm{m}^{3} \mathrm{u} / \mathrm{h}$ & 48380 & 48295 & 29736 & 28977 \\
\hline
\end{tabular}

\subsection{Calculation of maximum emission}

For the two analyzed cases, a maximum variant was assumed for the calculations, which means that it was assumed that for the maximum instantaneous fuel consumption there was a maximum flue gas flow rate and maximum emission limit values, i.e. not exceeding emission standards (emission standards given in Table 5 according to the Ordinance of the Minister of the Environment on emission standards for certain types of installations, sources of fuel combustion and incineration or co-incineration equipment [11] which adopted the regulations of IED [12]. A total of 7,500 hours of operation per year identical for all analyzed variants was assumed.

Table 5. Applicable emission standards for the analyzed variants.

\begin{tabular}{|c|c|c|c|c|c|c|c|c|}
\hline Boiler & Unit & OP-140 & $\begin{array}{c}3 \mathbf{x} \\
\text { OR-32 }\end{array}$ & $\begin{array}{c}\text { Gas } \\
\text { block }\end{array}$ & WtE & $\begin{array}{c}\text { WtE- } \\
\text { RDF }\end{array}$ & WR-10 & WR-25 \\
\hline $\mathrm{SO}_{2}$ & $\mathrm{mg} / \mathrm{m}^{3} \mathrm{u}$ & 250 & 1300 & 35 & 50 & 50 & 1300 & 1300 \\
\hline $\mathrm{NO}_{\mathrm{x}}$ & $\mathrm{mg} / \mathrm{m}^{3} \mathrm{u}$ & 200 & 400 & 200 & 200 & 200 & 400 & 400 \\
\hline $\begin{array}{c}\mathrm{TSP} \\
\text { (Total } \\
\text { suspended } \\
\text { particles) }\end{array}$ & $\mathrm{mg} / \mathrm{m}^{3} \mathrm{u}$ & 25 & 100 & 5 & 10 & 10 & 100 & 100 \\
\hline
\end{tabular}


For these assumed maximum values, in the next part of the calculations, the maximum emission of the three main pollutants from the combustion process, i.e. sulfur dioxide $\left(\mathrm{SO}_{2}\right)$, nitrogen oxides $\left(\mathrm{NO}_{x}\right)$ converted to nitrogen dioxide, and both instantaneous and annual particulate matter emissions were estimated. Results of these calculations are compiled for the first and second analyzed case, for all variants, in Tables 6 and 7, respectively.

Table 6. Maximum and annual emissions for five variants of the first case.

\begin{tabular}{|c|c|c|c|c|c|c|}
\hline Boiler & Unit & OP-140 & 3 x OR-32 & Gas block & WtE & WtE-RDF \\
\hline $\mathrm{SO}_{2}$ & $\mathrm{~kg} / \mathrm{h}$ & 39.51 & 217.02 & 5.28 & 16.77 & 12.64 \\
\hline $\mathrm{NO}_{\mathrm{x}}$ & $\mathrm{kg} / \mathrm{h}$ & 31.61 & 66.77 & 30.20 & 67.06 & 50.55 \\
\hline $\mathrm{TSP}$ & $\mathrm{kg} / \mathrm{h}$ & 3.95 & 16.69 & 0.75 & 3.35 & 2.53 \\
\hline $\mathrm{SO}_{2}$ & $\mathrm{~kg} /$ year & 296328 & 1627633 & 39635 & 125739 & 94779 \\
\hline $\mathrm{NO}_{\mathrm{x}}$ & $\mathrm{kg} /$ year & 237063 & 500810 & 226485 & 502955 & 379116 \\
\hline $\mathrm{TSP}$ & $\mathrm{kg} /$ year & 29633 & 125203 & 5662 & 25148 & 18956 \\
\hline
\end{tabular}

Table 7. Maximum and annual emissions for WR-10 and WR-25 boilers compared to the corresponding WtE-RDF.

\begin{tabular}{|c|c|c|c|c|c|}
\hline Boiler & Unit & WR-25 & WtE-RDF & WR-10 & WtE-RDF \\
\hline $\mathrm{SO}_{2}$ & $\mathrm{~kg} / \mathrm{h}$ & 62.89 & 2.41 & 38.66 & 1.45 \\
\hline $\mathrm{NO}_{\mathrm{x}}$ & $\mathrm{kg} / \mathrm{h}$ & 19.35 & 9.66 & 11.89 & 5.80 \\
\hline $\mathrm{TSP}$ & $\mathrm{kg} / \mathrm{h}$ & 4.84 & 0.48 & 2.97 & 0.29 \\
\hline $\mathrm{SO}_{2}$ & $\mathrm{~kg} /$ year & 471706 & 18111 & 289927 & 10866 \\
\hline $\mathrm{NO}_{\mathrm{x}}$ & $\mathrm{kg} /$ year & 145140 & 72443 & 89208 & 43466 \\
\hline $\mathrm{TSP}$ & $\mathrm{kg} /$ year & 36285 & 3622 & 22302 & 2173 \\
\hline
\end{tabular}

\subsection{Calculations of pollutant immissions}

According to the Environmental Protection Act in force in Poland, the emission of pollutants from the installation should not only meet the emission standards (if any), but also the emissions should not exceed environmental quality standards (i.e. in this case the permissible concentrations of pollutants in the atmospheric air - reference values). Therefore, in addition to the comparison of the emissions from the thermal waste treatment system with the emissions from heating installations pollutant immisions from the analyzed installations were also compared.

In the first part pollutant immissions from the OP-140 pulverized coal-fired boilers, three OR-32 stoker-fired boilers and gas block of a similar total heat output (about 105 $\mathrm{MW}_{\mathrm{t}}$ ) were compared with immissions from the thermal waste treatment facility (WtE) - a classical incineration plant and thermal waste treatment facility fired with alternative RDF fuel (WtE-RDF).

The second part analyzes immissions of pollutants from one of the WR-10 and WR-25 stoker-fired boilers in comparison with the thermal RDF treatment facility of similar heat output.

Calculations of immission pollutants were made using the Polish methodology given in the regulation of the Minister of Environment on reference values for some substances in the air, based on Pasquill atmospheric diffusion model $[13,14]$. Emissions of sulfur dioxide, nitrogen oxides and particulate matter given in Tables 6 and 7 as well as flue gas parameters given in Tables 3 and 4 were taken for calculations.

In order to maintain identical conditions of pollutant diffusion in the atmosphere, the emitter height was assumed to be $60 \mathrm{~m}$ and its diameter was chosen to be about $20 \mathrm{~m} / \mathrm{s}$. This gave a diameter of $1.9 \mathrm{~m}$ for the gas block, $2.0 \mathrm{~m}$ for the OP-140 boiler, $2.3 \mathrm{~m}$ for 
three OR-32 boilers, $2.8 \mathrm{~m}$ for the RDF incinerator and $3.1 \mathrm{~m}$ for the mixed municipal waste incineration plant. In the second case an emitter of $50 \mathrm{~m}$ was adopted. As in the previous example, the diameter of the emitter was different: for the WR-10 boiler it was 1.2 $\mathrm{m}$, and for the corresponding RDF boiler with heat output of about $12 \mathrm{MW}_{\mathrm{t}}-1.6 \mathrm{~m}$, while for the WR-25 boiler - $1.8 \mathrm{~m}$ and $2.4 \mathrm{~m}$ for the corresponding RDF boiler with heat output of about $30 \mathrm{MW}_{\mathrm{t}}$. That gave the same outlet velocity for both cases compared - about 7.7 $\mathrm{m} / \mathrm{s}$ for the WR-25 boiler and about $7 \mathrm{~m} / \mathrm{s}$ for the WR-10. Results of the modeling of spread of pollutants in the form of calculated concentrations in one-hour and average annual immissions are presented in Tables 8 to 11 .

Table 8. Maximum calculated one-hour concentrations in the immission within the range of an emitter for five variants analyzed.

\begin{tabular}{|c|c|c|c|c|c|c|c|}
\hline Pollutant & Unit & OP-140 & 3 x OR-32 & Gas block & WtE & WtE-RDF & $\begin{array}{c}\text { Permissible } \\
\text { value }\end{array}$ \\
\hline $\mathrm{SO}_{2}$ & $\mu \mathrm{g} / \mathrm{m}^{3}$ & 62.041 & 269.368 & 8.288 & 13.835 & 12.236 & 350 \\
\hline $\mathrm{NO}_{\mathrm{x}}$ & $\mu \mathrm{g} / \mathrm{m}^{3}$ & 49.636 & 82.876 & 47.404 & 55.324 & 48.933 & 200 \\
\hline $\mathrm{PM} 10$ & $\mu \mathrm{g} / \mathrm{m}^{3}$ & 3.101 & 10.358 & 0.589 & 1.382 & 1.225 & 280 \\
\hline
\end{tabular}

Table 9. Maximum calculated average annual concentrations in the immission within the range of an emitter for five variants analyzed.

\begin{tabular}{|c|c|c|c|c|c|c|c|}
\hline Pollutant & Unit & OP-140 & 3 x OR-32 & $\begin{array}{c}\text { Gas } \\
\text { block }\end{array}$ & WtE & WtE-RDF & $\begin{array}{c}\text { Permissible } \\
\text { value }\end{array}$ \\
\hline $\mathrm{SO}_{2}$ & $\mu \mathrm{g} / \mathrm{m}^{3}$ & 1.924 & 8.492 & 0.257 & 0.437 & 0.392 & 20 \\
\hline $\mathrm{NO}_{\mathrm{x}}$ & $\mu \mathrm{g} / \mathrm{m}^{3}$ & 1.539 & 2.613 & 1.470 & 1.747 & 1.576 & 40 \\
\hline $\mathrm{PM} 10$ & $\mu \mathrm{g} / \mathrm{m}^{3}$ & 0.096 & 0.327 & 0.018 & 0.044 & 0.039 & 40 \\
\hline $\begin{array}{c}\text { Dust } \\
\text { precipitation }\end{array}$ & $\mathrm{g} / \mathrm{m}^{2}$ year & 2.574 & 9.067 & 0.489 & 1.250 & 1.107 & 200 \\
\hline
\end{tabular}

Table 10. Maximum calculated one-hour concentrations in the immissions within the range of an emitter for WR-10 and WR-25 boilers compared to the corresponding TWTF-RDF.

\begin{tabular}{|c|c|c|c|c|c|c|}
\hline Pollutant & Unit & WR-25 & WtE-RDF & WR-10 & WtE-RDF & $\begin{array}{c}\text { Permissible } \\
\text { value }\end{array}$ \\
\hline $\mathrm{SO}_{2}$ & $\mu \mathrm{g} / \mathrm{m}^{3}$ & 354.119 & 20.738 & 319.180 & 12.655 & 350 \\
\hline $\mathrm{NO}_{\mathrm{x}}$ & $\mu \mathrm{g} / \mathrm{m}^{3}$ & 108.955 & 83.123 & 98.165 & 50.618 & 200 \\
\hline $\mathrm{PM}^{30}$ & $\mu \mathrm{g} / \mathrm{m}^{3}$ & 13.626 & 2.065 & 12.260 & 1.265 & 280 \\
\hline
\end{tabular}

Table 11. Maximum calculated average annual concentrations in the immissions within the range of an emitter for WR-10 and WR-25 boilers compared to the corresponding TWTF-RDF.

\begin{tabular}{|c|c|c|c|c|c|c|}
\hline Pollutant & Unit & WR-25 & WtE-RDF & WR-10 & WtE-RDF & $\begin{array}{c}\text { Permissible } \\
\text { value }\end{array}$ \\
\hline $\mathrm{SO}_{2}$ & $\mu \mathrm{g} / \mathrm{m}^{3}$ & 11.216 & 0.575 & 8.942 & 0.349 & 20 \\
\hline $\mathrm{NO}_{\mathrm{x}}$ & $\mu \mathrm{g} / \mathrm{m}^{3}$ & 3.482 & 3.304 & 2.750 & 1.398 & 40 \\
\hline $\mathrm{PM} 10$ & $\mu \mathrm{g} / \mathrm{m}^{3}$ & 0.435 & 0.057 & 0.343 & 0.035 & 40 \\
\hline $\begin{array}{c}\text { Dust } \\
\text { precipitation }\end{array}$ & $\mathrm{g} / \mathrm{m}^{2}$ year & 13.276 & 1.595 & 9.650 & 0.972 & 200 \\
\hline
\end{tabular}

At the same time, when analyzing the data in Tables 5 to 8 , one can see that in most cases the pollutant emissions do not exceed air quality standards (permissible one-hour concentrations and permissible average annual concentrations) as required by article 144 of the Law on Environmental Protection [15].

As can be easily observed, most pollutants (both $\mathrm{SO}_{2}$ and $\mathrm{NO}_{\mathrm{x}}$, as well as particulate matter) emitted to the atmosphere are generated by stoker-fired boilers. This is due to the 
relatively liberal emission standards for the existing sources of heat output below $50 \mathrm{MW}_{\mathrm{t}}$. The smallest amount of pollutants is emitted to the air by gas blocks. A comparison of emissions of sulfur dioxide and particulate matter from waste incineration plants (both mixed and RDF) with the emissions from coal-fired heat plants (equipped with both pulverized coal- and stoker-fired boilers) is far better in favor of the waste incineration plants. Only in the case of emissions of nitrogen oxides, the emissions from the incineration plant are comparable to the emissions from the stoker-fired boilers. The other boiler rooms (with pulverized coal-fired boilers and gas block) are better. This is due to the relatively low calorific value of both mixed municipal waste $(7.5 \mathrm{MJ} / \mathrm{kg})$ and $\mathrm{RDF}(14 \mathrm{MJ} / \mathrm{kg})$, and therefore the need to burn much more fuel which results in significant flue gas emissions with identical emission standards applicable to all installations, i.e. $200 \mathrm{mg} / \mathrm{m}^{3}$ u.

\section{Results}

Pollutant emissions for both analyzed cases are compared in Tables 6 and 7. Similarly, the results of calculations of the spread of pollutants from the analyzed sources in the form of calculated pollutant concentrations in imission are summarized in Tables 8 to 11 .

\section{Conclusions}

The calculations show that most of the pollutants are generated by coal-fired stoker-boilers and least by gas blocks, while the emission from pulverized coal-fired boilers is slightly lower than the emission from stoker-fired boilers, because other emission standards are decisive in this case. It is worth noting that emissions from the waste thermal treatment plant (both mixed and RDF) are slightly higher than those from the gas block. The comparison of emissions of pollutants from particular coal-fired boilers commonly used in Polish heating industry is far worse than that of incineration plants for municipal waste (mixed and RDF).

It is therefore safe to say that despite many protests and public reluctance to build a Municipal Waste Thermal Treatment Plant (Waste-to-Eneregy - WtE) or WtE-RDF facilities, they are a significantly smaller source of environmental pollution than the wellknown and widely accepted coal-fired heating systems.

In conclusion, this work was aimed at comparing the impact of emissions from boilers commonly used in the heating sector with the municipal waste incineration plant (both mixed and RDF). From the presented results it can be clearly seen that thermal treatment of municipal waste and WtE-RDF has no significant environmental impact. This method is generally used as an indispensable part of the municipal waste management system, proven and functioning in the most industrialized countries not only of the European Union [2].

\section{References}

1. Statistical Yearbook Environmental Protection - Polish State Statistical Office, Warsaw 1990-2016

2. G. Wielgosiński, Thermal Treatment of Municipal Solid Waste - selected problems. (Nowa Energia Publishing Office, Racibórz 2016)

3. O. Namiecińska, G. Wielgosiński, A. Targaszewska, Nowa Energia, 1, 18-22 (2017)

4. Ordinance of the Minister of Economy of 16 July 2015 on the acceptance of waste for landfill (Dz. U. 2015, poz. 1277) 
5. G. Wielgosiński., O. Namiecińska, Nowa Energia, 2, 11-20 (2016)

6. G. Wielgosiński., Nowa Energia, 4, 8-16 (2015)

7. W. Bujalski, J. Lewandowski, Perspectives of implementation of MCP Directive standards in heating industry in Poland. Proceedings of Warsaw Climate and Energy Talks, (2014)

8. Directive (EU) 2015/2193 of the European Parliament and of the Council of 25 November 2015 on the limitation of emissions of certain pollutants into the air from medium combustion plants - O.J. 2015, L 313, 1-19

9. B. Regulski, W. Bujalski, The heat supply sector in Poland, Proceedings of Warsaw Climate and Energy Talks, (2014)

10. H. Recknagel, E. Sprenger, W. Hönmann, E.R. Schramek, Taschenbuch für Heizung und Klimatechnik. - R. Oldenburg Verlag, München, (1994)

11. Ordinance of the Minister of the Environment of 4 November 2014 on emission standards for certain types of installations, fuel sources and combustion or coincineration facilities (Dz. U. 2014, poz. 1546)

12. Directive 2010/75/EU of The European Parliament and of The Council of 24 November 2010 on industrial emissions (integrated pollution prevention and control) O.J. 2010, L 334, 17-119

13. Ordinance of the Minister of the Environment of 26 January 2010 on reference values for certain substances in the air (Dz. U. 2010, Nr 16, poz. 87)

14. S. Douw, M. Rohit, Air Pollution Modeling and its Application. - (Springer 2014)

15. Act of 27 April 2001 on the Environmental Protection Law ( Dz. U. 2017 poz. 519, $785,898,1089)$ 